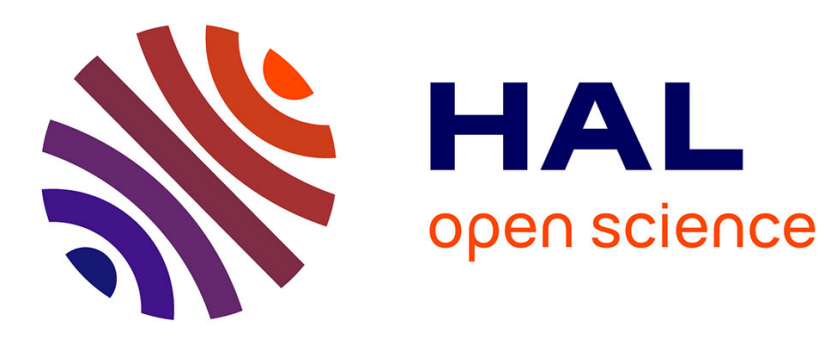

\title{
Identification of market adulterants in East Indian sandalwood using DNA barcoding
}

\author{
Arun Suma, E. M. Muralidharan, P. Sujanapal, M. Balasundaran
}

\section{To cite this version:}

Arun Suma, E. M. Muralidharan, P. Sujanapal, M. Balasundaran. Identification of market adulterants in East Indian sandalwood using DNA barcoding. Annals of Forest Science, 2014, 71 (6), pp.517-522. 10.1007/s13595-013-0354-0 . hal-01101762

\section{HAL Id: hal-01101762 https://hal.science/hal-01101762}

Submitted on 9 Jan 2015

HAL is a multi-disciplinary open access archive for the deposit and dissemination of scientific research documents, whether they are published or not. The documents may come from teaching and research institutions in France or abroad, or from public or private research centers.
L'archive ouverte pluridisciplinaire HAL, est destinée au dépôt et à la diffusion de documents scientifiques de niveau recherche, publiés ou non, émanant des établissements d'enseignement et de recherche français ou étrangers, des laboratoires publics ou privés. 


\title{
Identification of market adulterants in East Indian sandalwood using DNA barcoding
}

\author{
Suma Arun Dev • E. M. Muralidharan • P. Sujanapal • \\ M. Balasundaran
}

Received: 23 April 2013 / Accepted: 2 December 2013 / Published online: 17 December 2013

(C) INRA and Springer-Verlag France 2013

\begin{abstract}
- Context East Indian sandalwood (Santalum album L.) in commercial markets is highly prone to adulteration. A number of cases were registered with regard to the adulteration of East Indian sandalwood, but the lack of technical tools for the precise species identification of the source wood stalled most of the court cases.

- Aims The standard DNA barcode regions, the $r b c L$, matK and $t r n H-p s b A$ chloroplast genomic sequences recommended by the Consortium of Barcode of Life (COBOL) were analysed to distinguish wood adulterants of East Indian sandalwood.

- Methods Standard polymerase chain reactions with COBOL recommended primers were performed for all three barcode loci. The PCR products after gel elution were sequenced and alignments were performed using CLUSTALX.

- Results Single nucleotide polymorphisms (SNPs) identified with $r b c L$ and $t r n H-p s b A$ sequences of Erythroxylum monogynum Roxb. as well as with matK sequences of Osyris wightiana Wall ex. Wight could be efficiently utilized for the detection/monitoring of East Indian sandalwood adulterants. Among the two common adulterants $O$. wightiana
\end{abstract}

\section{Handling Editor: Christophe PLOMION}

Contribution of the co-authors Suma Arun Dev: contributed towards designing and conducting wet lab experiments, writing paper and analysing the data

E.M. Muralidharan: involved in writing paper and coordination of project P. Sujanapal: sample collections from the field site and identification

M. Balasundaran: wood sample collection and involved in writing paper

S. A. Dev $(\bowtie) \cdot$ E. M. Muralidharan · P. Sujanapal

Kerala Forest Research Institute, Peechi, Trichur,

Kerala 680653, India

e-mail:sumadev@kfri.res.in

M. Balasundaran

Tropical Institute of Ecological Sciences, Velloor P.O., Kottayam, Kerala 686501, India and E. monogynum, the former was more similar to S. album and grouped together in the dendrogram.

- Conclusion The study recommends the exploitation of DNA barcoding technique using standard barcodes to trace sandalwood timber adulterants.

Keywords Santalum album · Adulterants · DNA barcoding · Single nucleotide polymorphisms (SNPs)

\section{Introduction}

Sandalwood, the most valuable tropical hardwood, is mainly extracted from Santalum album L. (East Indian sandalwood) and Santalum spicatum R.Br (Australian sandalwood) (Hewson and George 1984). In India, S. album is distributed naturally over $9,400 \mathrm{~km}^{2}$ on the Deccan Plateau in the states of Karnataka, Kerala and Tamil Nadu (Srimathi et al. 1995). Indian sandalwood is the most appreciated in the world, for its fragrant heartwood and oil used for incenses, soaps, creams, perfumes, carvings, paintings and for religious rituals for over 4,000 years. The global supply of wild Indian sandalwood has reached critical levels due to poaching and overharvest with the tree being recognised as a vulnerable species on the World Conservation Union's Threatened Species Red List (IUCN 2009). In India, official production of sandalwood has thus declined significantly over the years due to the depletion of the existing natural resources (Ananthapadmanabha 2012).

To supplement internal demands, which are 5,000 t per annum, India has to adopt sandalwood import in substantial quantity and the import of substitutes especially the 'Tanzanian or African sandalwood', Osyris lanceolata Hochst. \& Steud. was more than 3,000 t in 2006 (Ananthapadmanabha 2012). Consequently, the quality of superior sandalwood oil was affected and the government 
had to impose a ban on import of sandalwood in India. The East Indian sandalwood oil is very unique with a large number of essential molecules which are extremely difficult to replace with a synthetic substitute. The common sandalwood adulterants available in commercial market of India are the 'Nepal sandalwood', Osyris wightiana Wall. ex Wight (Santalaceae) and 'Indian bastard sandal', Erythroxylum monogynum Roxb. (Erythroxylaceae) (Anupama et al. 2012). It is difficult to distinguish between $O$. wightiana and 'East Indian sandalwood' in grain or colour with the scent of the two woods differing only slightly. The heart wood is faintly fragrant and used for adulterating sandalwood (Shyaula 2012). The heartwood of E. monogynum is reddish-brown and with a pleasant odour (Oyen and Dung 1999).

A number of lawsuits registered with regard to the adulteration of sandalwood and oil get stalled due to the lack of technical tools for the correct identification of the source wood (Bhat et al. 2006). The ability to track or identify timber resources of economic value is therefore critically essential for the effective management and appropriate regulation of timber trade. DNA barcoding has been suggested as a valid technical tool even in the court of law (Lowe and Cross 2011) and can replace other timber species verification means like wood anatomy (Bhat et al. 2006), chemical composition (Deguilloux et al. 2002) and isotopic fingerprinting (Boner et al. 2007), which in the majority of cases are unable to resolve down to the species level. DNA barcoding, as facilitated by the Consortium for the Barcode of Life and the International Barcode of Life Project, has developed a standardized set of gene regions and central database of reference samples (Barcode of Life Database-BOLD) to identify many species around the world (Hebert et al. 2003; Costion et al. 2011). Developments over the last 10 years in the extraction of DNA from dried and processed wood samples lead to the development of reliable and efficient tracing methods particularly for forest trees affected by illegal logging and adulteration activities (Deguilloux et al. 2002; Liepelt et al. 2006; Rachmayanti et al. 2006; Lowe et al. 2010).

This paper reports the ability of DNA barcoding, using three standard plant barcodes, to distinguish East Indian sandalwood from its adulterant species viz $O$. wightiana and E. monogynum.

\section{Material and methods}

\subsection{DNA extraction}

Leaf samples of $S$. album as well as of the adulterants $O$. wightiana and E. monogynum were collected from the Marayur sandalwood reserve forest and Chinnar Wildlife Sanctuary located on the leeward side of the Western Ghats in the South West region of India $\left(10^{\circ} 15^{\prime} \mathrm{N}\right.$ latitude and $77^{\circ} 11^{\prime}$ E longitude). Voucher specimens for all the species were deposited at the KFRI herbaria maintained in the institute. DNA was also extracted from dried wood logs and stored using QIAGEN DNeasy plant mini kit following the manufacturer's protocol (QIAGEN, Germany). The extracted DNA was quantified using NanoDrop spectrophotometer (Thermo Fisher Scientific, USA) at $260 \mathrm{~nm}$.

\subsection{PCR amplification and sequencing}

Polymerase chain reaction (PCR) amplifications were performed in five samples each for the three standard barcode loci viz $r b c L$ (ribulose bisphosphate carboxylase) and matK (maturase $\mathrm{K}$ ) as well as for the non-coding $\operatorname{trnH}-p s b A$ intergenic spacer region of the plastid genome. PCR amplifications were carried out using COBOL Plant Working Group (2009) recommended universal primers for $r b c L$, matK, and trnH-psbA listed in Table 1. PCR was performed using a PTC-100 thermocycler (MJ Research Inc., USA) and the target fragments amplified consistently. PCR reaction mix included $3 \mathrm{U}$ of Taq polymerase enzyme, $200 \mu \mathrm{M}$ dNTPs, $50-100 \mathrm{ng}$ of genomic DNA and 20 pmol of the respective forward and reverse primers for a final reaction volume of $20 \mu \mathrm{l}$. Amplified products were resolved on $2 \%$ agarose gel and documented using Alpha Gel Imager (Alpha Innotech, USA). PCR products were purified with a gel elution/PCR clean-up dual Nucleospin kit (Machery-Nagel, USA). Cycle sequencing reactions were performed using Big Dye Terminator cycle sequencing chemistry in a $\mathrm{ABI}$ sequencer (M/s SciGenom, Cochin, India). The markers were sequenced in single direction if the single strand had a high-quality read, or wherever required in both directions.
Table 1 Barcode loci and primer information

\begin{tabular}{lll}
\hline Barcode loci & Primer information & Primer annealing temperature \\
\hline$r b c L$ & 1 F ATGTCACCACAAACAGAAAC & $60{ }^{\circ} \mathrm{C}$ \\
& 724R TCGCATGTACCTGCAGTAGC & \\
$m a t K$ & 472 F CCRTCATCTGGAAATCTTGGTT & $60{ }^{\circ} \mathrm{C}$ \\
& 1248R GCTRTRATAATGAGAAAGATT TCTGC & \\
$t r n H-p s b A$ & $t r n h F$ CGCGCATGGTGGATTCACAATCC & $60.8{ }^{\circ} \mathrm{C}$ \\
& $p s b A$ RGTWATGCAYGAACGTAATGCTC & \\
\hline
\end{tabular}


Fig. $1 r b c L$ DNA barcodes for S. album, O. wightiana and

E. monogynum
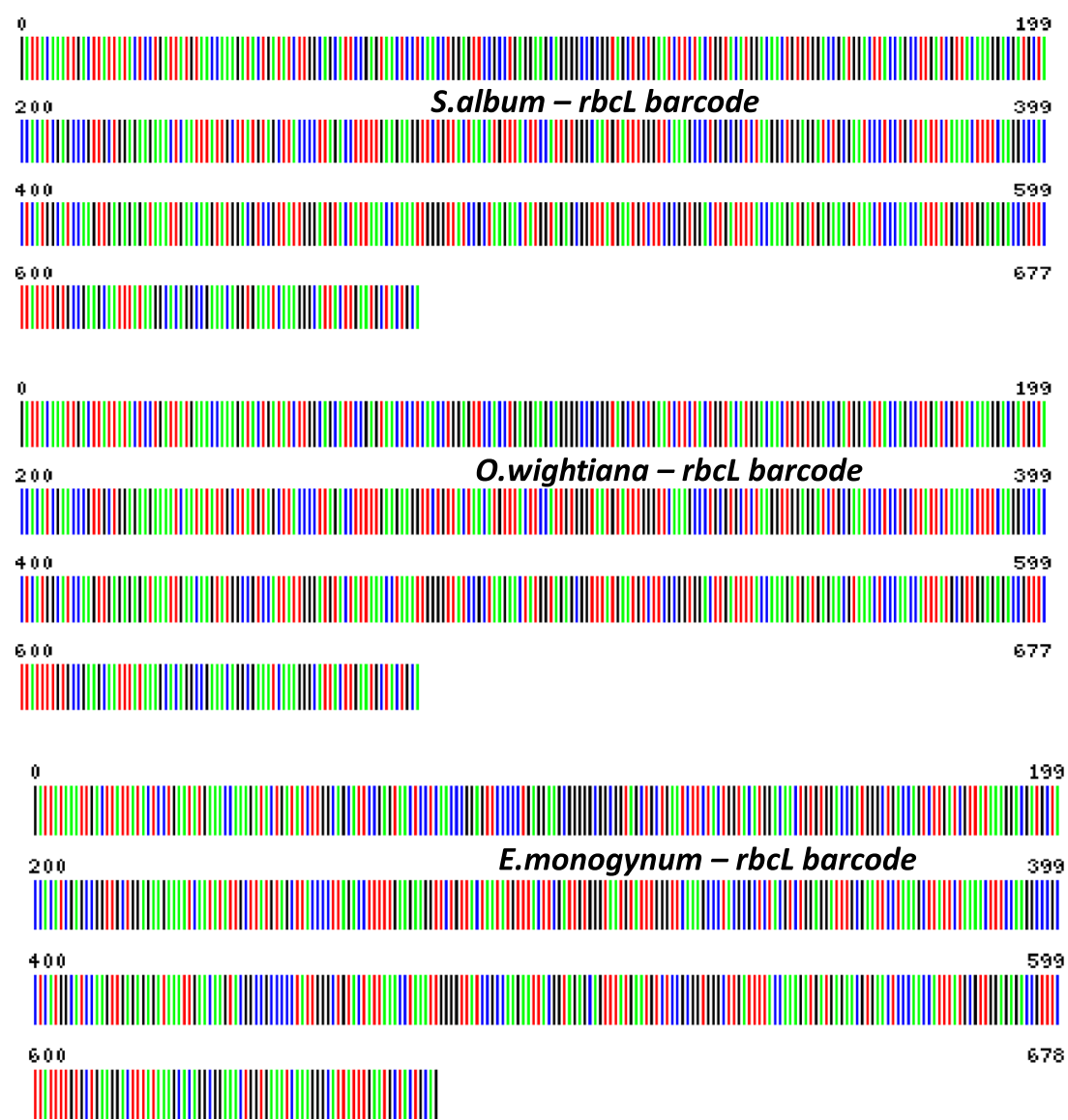

2.3 Sequence analysis, barcode design and phylogeny construction

Sequences were edited using Bioedit software (Biological sequence alignment editor) (Hall 1999) and were aligned using CLUSTALX (version 2.0.11) with default parameters for locating single nucleotide polymorphisms (SNPs) in each of the analysed sequences (Larkin et al. 2007). Edited sequences were submitted into NCBI GenBank (http://www. ncbi.nlm.nih.gov/genbank/) as well as BOLD public domain (http://www.boldsystems.org/). Basic sequence analysis was carried out using molecular evolutionary genetics analysis (MEGA, version 4) (Tamura et al. 2007). Sequence statistics including conserved sites, variable sites and parsimony informative sites were calculated using default parameters in MEGA 4. Sequences were also manually aligned using Alignment Explorer in MEGA 4. Genetic distance analysis was conducted using the Kimura 2-parameter method in
MEGA 4. Sequences of $r b c L$, matK and trnH-psbA of Buxus sempervirens available in the NCBI nucleotide library (accession nos. HE963366.1, HE966887.1, HE966523.1, respectively) were also included in the distance analysis. All positions containing gaps and missing data were eliminated from the dataset (complete deletion option). There were 1,358 positions in the final dataset.

\section{Results}

All selected barcode regions were amplified with the COBOL primers and the eluted products gave good read length in the forward direction. Molecular diagnosis of sandalwood adulterants were performed by a multi-locus DNA barcoding approach. The final aligned partial sequences had a length of 679, 710 and $443 \mathrm{bp}$ for rbcL, matK and trnH-psbA intergenic spacer, respectively (NCBI GenBank accession
Table 2 Basic statistics for barcode analysis

\begin{tabular}{lllcl}
\hline Loci & Conserved & Variable & Parsimony informative & Overall transition/trasversion ratio (R) \\
\hline rbcL & 617 & 61 & $9(1 \%)$ & 1.6 \\
matK & 560 & 110 & $15(2 \%)$ & 1.4 \\
trnH & 242 & 153 & $7(2 \%)$ & 0.7 \\
\hline
\end{tabular}



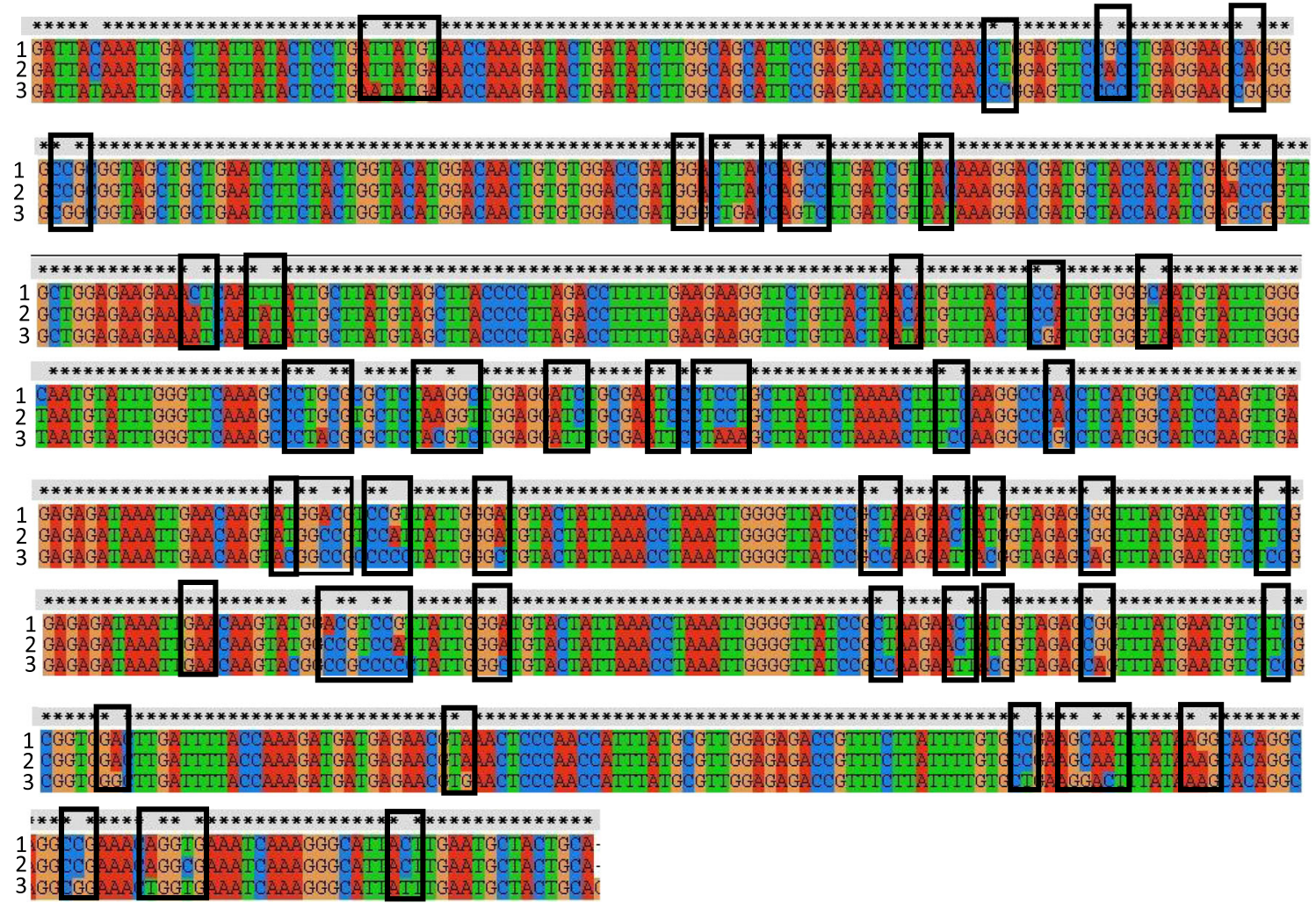

Fig. 2 Multiple sequence alignment showing single nucleotide polymorphisms (SNPs) (highlighted in boxes) in $r b c L$ sequences of $S$. album (1), $O$. wightiana (2) and E. monogynum (3)

nos. KC503279-KC503287). Unique barcodes using $r b c L$, $m a t K$ and $p s b A$-trn $H$ were generated for sandalwood and its adulterants through BOLD (http://www.boldsystems.org/) and the $r b c L$ barcodes are provided in Fig. 1.

Of the total number of aligned nucleotides, conserved sites, variable but uninformative and parsimony informative sites showed variation among the three standard barcodes (Table 2). Generally, a very low percentage of parsimony informative characters of 1 or $2 \%$ were observed with all the three analysed barcodes. Transitions were more common than transversions except for trn $H-p s b A$ and hence transition/ trasversion ratio was $>1$ in $r b c L$ and $m a t K$. We manually examined the sequence alignments for SNPs and found unique SNPs in sandalwood and its adulterants (Fig. 2). Unique SNPs were observed with $r b c L$ and $t r n H-p s b A$ of E. monogynum and also in the matK $\mathrm{Karcode}$ of $O$. wightiana .

Estimates of genetic distances among sandalwood and its adulterants were calculated using the Kimura 2-parameter method in MEGA 4 (Kimura 1980) with a total of 1,358 positions in the combined dataset. The genetic distance between S. album/O. wightiana was 0.037 and that of S. album/ E. monogynum was 0.080 . Aligned molecular sequence data from all the three barcodes were used to generate a dendrogram which depicted the genetic relationship among sandalwood and its common adulterants. S. album and $O$. wightiana formed the most genetically similar cluster (Fig. 3).

\section{Discussion}

DNA barcoding offers numerous potential applications in the field of forest forensics including the identification of timber species in the timber trade industry as well as to monitor the illegal trade of wildlife, such as protected or endangered species or to identify the species of origin in the case of commercially processed food (Shivji et al. 2002). DNA barcoding has been employed to identify an endangered tropical timber species, Gonystylus bancanus (Asif and Cannon 2005) as well as to identify wood of Shorea sp. and its origin by the Forestry and Forest Products Research Institute (Tsukuba), the Forest Research Centre, Sabah as well as by the Forest Research Institute Malaysia (Fuji 2007). In the Royal Botanic Gardens, Kew, DNA barcoding has been employed to detect certain timber species associated with

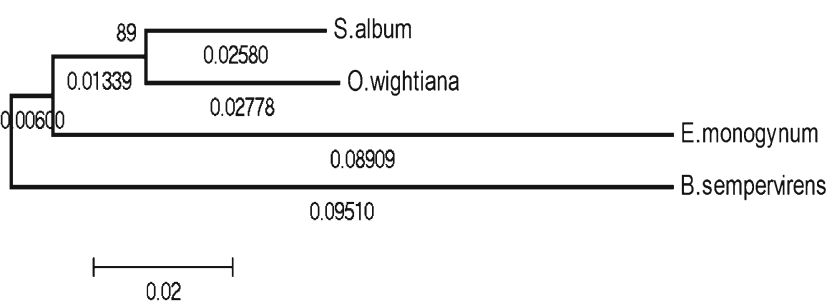

Fig. 3 Dendrogram depicting genetic relationships of sandalwood and its adulterants (values indicate genetic distances) 
CITES such as Aquilaria and Cedrela, in illegally harvested timber (Chase et al. 2005).

The present study demonstrated the usefulness of DNA barcodes to distinguish common wood adulterants from the original sandalwood. Out of the three barcodes tested, unique SNPs were identified with two of the standard barcodes viz $r b c L$, trnH-psbA in E. monogynum and with matK barcode in $O$. wightiana which can be efficiently used for the genetic identification of sandalwood adulterants. SNPs have been used previously also for the timber tracking of wood adulterants (Degen and Fladung 2008). Among the two adulterants, $O$. wightiana was found to be more genetically similar to S. album as revealed in the distance-based dendrogram. Earlier studies on genetic grouping based on rDNA sequences revealed close genetic affinities of S. album and $O$. wightiana (Anupama et al. 2012). In the barcodes, transitions, which mostly do not result in amino acid changes, were more frequent than transversions. Since barcode genes are more conserved, transitions which do not make any change in the amino acid sequence occur more frequently and DNA sequences in general are more likely to undergo transition than transversion with the ti/tv ratio above unity (Holmquist 1983).

The Indian species of sandalwood (S. album) commands the highest price up to $\mathrm{A} \$ 105,000$ per tonne at auction due to its superior oil yields and long-term market acceptance. An unfortunate consequence due to these rising prices is that some dealers are even using polished and scented sticks of most inferior quality woods which are difficult to identify by traditional means (Page et al. 2012). The ability of the standard DNA barcodes to differentiate sandalwood adulterant species demonstrated in the present study can be effectively utilized as a diagnostic adulterant monitoring tool by enforcement agencies (customs/border inspection) and traders of sandalwood and its products. The new technological advancements in the timber forensics have minimised the need for basic skills as well as dramatically reduced the cost, so that it can complement an integrated approach even in the court of law.

\section{Conclusions}

The present study demonstrated the potential of DNA barcodes to differentiate market adulterants from the original East Indian sandalwood. Single nucleotide polymorphisms observed in the adulterants of original sandalwood clearly indicated the utility of DNA barcoding to track the wood adulterants in Indian sandalwood industry. Recent technological innovations and high level of automation have reduced the expenses and the technical skills required for the execution of DNA barcoding technique. Practical checks at the credible voluntary wood certification agencies as well as in the court of law could be made tamper proof by the implementation of
DNA barcoding along with the existing traditional techniques for timber monitoring.

Acknowledgments We are grateful to the Kerala Forest Department (KFD) for permission to collect the samples. We would also like to thank the anonymous reviewers for helpful suggestions and comments on the manuscript.

Funding The study was funded by Kerala State Council for Science, Technology and Environment (KSCSTE), Govt. of Kerala, India.

\section{References}

Ananthapadmanabha HS (2012) Expert sandalwood marketing report, TFS sandalwood project report, pp 69-71

Anupama C, Balasundaran M, Sujanapal P (2012) Phylogenetic relationships of Santalum album and its adulterants as inferred from nuclear DNA sequences. Int J Agric For 2:150-156

Asif MJ, Cannon CH (2005) DNA extraction from processed wood: a case study for the identification of an endangered timber species (Gonystylus bancanus). Plant Mol Biol Report 23:185-192

Bhat KV, Balasundaran M, Balagopalan M (2006) Identification of Santalum album and Osyris lanceolata through morphological and biochemical characteristics and molecular markers to check adulteration. KFRI Res Rep 307:22p

Boner M, Sommer T, Erven C, Forstel H (2007) Stable isotopes as a tool to trace back the origin of wood. In: Proceedings of the international workshop, Fingerprinting methods for the identification of timber origins, October 8-9, Bonn/Germany, pp 47-57

Chase MW, Salamin N, Wilkinson M (2005) Land plants and DNA barcodes: short-term and long-term goals. Philos Trans R Soc Lond B Biol Sci 360:1889-1895

COBOL Plant Working Group (2009) A DNA barcode for land plants. Proc Nat Acad Sci 106:12794-12797

Costion C, Ford A, Cross H (2011) Plant DNA barcodes can accurately estimate species richness in poorly known floras. PLoS ONE 6: E26841. www.plosone.org

Degen B, Fladung, M (2008) Use of DNA-markers for tracing illegal logging. In: Degen B (ed) Proceedings of the international workshop "Fingerprinting methods for the identification of timber origins" October 8-9, Landbauforschung, VTI Agriculture and Forestry Research, Sonderheft 321, Germany, pp 6-14

Deguilloux MF, Premonge MH, Petit RJ (2002) Novel perspectives in wood certification and forensics: dry wood as a source of DNA. Proc R Soc Lond 269:1039-1046, Delhi

Fuji T (2007) Outline of the research project »Methods to identify wood species and origin of timber of Southeast Asia. Proceedings of the international symposium on development of improved methods to identify Shorea species wood and its origin, 19

Hall TA (1999) A user friendly biological sequence alignment editor and analysis program for Windows 95/98/NT. Nucleic Acid Symp Ser 41:95-98

Hebert PDN, Cywinska A, Ball SL (2003) Biological identifications through DNA barcodes. Proc R Soc Lond Biol Sci Series B 270: 313-321

Hewson HJ, George AS (1984) Santalaceae. In: George AS (ed) Flora of Australia. Australian Government Publishing Service, Canberra, pp 29-67

Holmquist R (1983) Transitions and transversions in evolutionary descent: an approach to understanding. J Mol Evol 19:134-144

IUCN (2009) IUCN Red List of Threatened Species. Version 2009.1, www.iucnredlist.org 
Kimura M (1980) A simple model for estimating evolutionary rates of base substitutions through comparative studies of nucleotide sequences. J Mol Evol 16:111-120

Larkin MA, Blackshields G, Brown NP (2007) Clustal W and ClustaL X version 2. Bioinformatics 23:2947-2948

Liepelt S, Sperisen C, Deguilloux MF (2006) Authenticated DNA from ancient wood remains. Ann Bot 98:1107-1111

Lowe AJ, Cross HB (2011) The application of DNA to timber tracking and origin verification. J Int Assoc Wood Anatomists 32:251-262

Lowe AJ, Wong KN, Tiong TS (2010) A DNA method to verify the integrity of timber supply chains, confirming the legal sourcing of Merbau timber from logging concession to sawmill. Silvae Genet 59:263-268

Oyen LPA, Dung NX (1999) Plant resources of south-east Asia No. 19, Essential-oil plants, Backhuys, Leiden, the Netherlands, 1999

Page T, Tate H, Bunt C, Potrawiak A, Berry A (2012) Opportunities for the smallholder sandalwood industry in Vanuatu. ACIAR Technical
Reports No 79 Australian Centre for International Agricultural Research, Canberra. $67 \mathrm{p}$

Rachmayanti Y, Leinemann L, Gailing O (2006) Extraction, amplification and characterization of wood DNA from Dipterocarpaceae. Plant Mol Biol Rep 24:45-55

Shivji M, Clarke C, Pank M (2002) Genetic identification of pelagic shark body parts for conservation and trade monitoring. Conserv Biol 16: $1036-1047$

Shyaula SL (2012) A review on genus Osyris: phytochemical constituents and traditional uses. J Nat Pharm 3:61-70

Srimathi RA, Kulkarni HD, Ventkatesan K (1995) Recent advances in research and management of sandal (Santalum album L.) in India. Associated publishing Co, New Delhi, 1995

Tamura K, Dudley J, Nei M (2007) MEGA4: molecular evolutionary genetics analysis (MEGA) software version 4.0. Mol Biol Evol 24: 1596-1599 